\title{
24. A különleges jogrendi esetkörök alkotmányos és törvényi szintū szabályozása Szlovákiában
}

\section{SZINEK JÁNOS -SZINEK CSÜTÖRTÖKI HAJNALKA}

\section{A különleges jogrend alkotmányos és törvényi szintủ szabályozása}

Szlovákiában a különleges jogrendre vonatkozó általános szabályok a Szlovák Köztársaság Alkotmányában, ${ }^{1}$ míg a részletszabályok a háború, hadiállapot, rendkívüli állapot és veszélyhelyzet idején az állam biztonságáról szóló alkotmánytörvényben ${ }^{2}$ kerültek rögzítésre. Ez utóbbit akár a Szlovák Köztársaság „válságalkotmányának” is nevezhetnénk, hiszen meghatározó szerepet játszik az állam szuverenitásának védelmében. ${ }^{3}$ Svák az állam bizton-

I Ústavný zákon č. 460/1992 Zb., Ústava Slovenskej republiky (a továbbiakban: alkotmány).

2 Ústavný zákon č. 227/2002 Z. z., o bezpečnosti štátu v čase vojny, vojnového stavu, výnimočného stavu a núdzového stavu v znení neskorších predpisov (a továbbiakban: Állambiztonsági alk.tv.).

3 Škrobák, 2020.

Dr. Szinek János

janos.szinek@mfi.gov.hu

kutató (Mádl Ferenc Összehasonlító Jogi Intézet)

PhD-hallgató (Miskolci Egyetem, Deák Ferenc Állam- és Jogtudományi Doktori Iskola)

Dr. Szinek Csütörtöki Hajnalka

kutató (Mádl Ferenc Összehasonlító Jogi Intézet)

PhD-hallgató (Miskolci Egyetem, Deák Ferenc Állam- és Jogtudományi Doktori Iskola)

Szinek, J., Szinek Csütörtöki H. (2021) 'A különleges jogrendi esetkörök alkotmányos és törvényi szintû szabályozása Szlovákiában' in Nagy, Z., Horváth, A. (szerk.) A különleges jogrend és nemzeti szabályozási modelljei, 530-548. o. Budapest: Mádl Ferenc Összehasonlító Jogi Intézet.

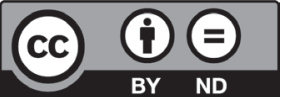


ságáról szóló alkotmánytörvényt az alkotmány háború vagy más rendkívüli helyzet idején alkalmazandó változatának nevezte. ${ }^{4}$

Míg az alkotmány meglehetősen szúkszavúan rendezi a különleges jogrenddel kapcsolatos kérdéskört, ${ }^{5}$ az állam biztonságáról szóló alkotmánytörvény a különleges jogrendi esetkörök taxatív felsorolását adja. Az alkotmánytörvényben egyenként meghatározták a különleges jogrend kihirdetésének feltételeit, a kihirdetés eljárási rendjét, az adott különleges jogrendi esetkör területi és időbeli hatályának, valamint az egyes alapvető jogok korlátozásának lehetőségét és az ezzel kapcsolatos kötelezettségeket. Az alkotmánytörvény továbbá szabályozza az egyes alkotmányos szervek múködésének sajátos rendjét is.

A szlovák jogrend kapcsán fontos kiemelni, hogy az alkotmányos rendszer nemcsak az alkotmányból, hanem az alkotmány mellett több alkotmánytörvényből (más néven: alkotmányos törvények vagy alkotmányerejü törvények) áll. Ezen oknál fogva a szlovák szakirodalom az ország alkotmányát polylegálisnak nevezi. ${ }^{6} \mathrm{Az}$ alkotmányos rend szerves részét alkotják tehát az egyéb alkotmánytörvények is, amelyeket az alkotmányban elöírt, az összes parlamenti képviselő háromötödös többségével (minősített többség) lehet elfogadni, illetve módosítani.7 Az alkotmány és az alkotmánytörvények viszonyának kérdésével a szlovák alkotmánybíróság is foglalkozott. Ennek kapcsán az alkotmánybíróság határozatában kimondta, hogy a jogrend legfelsőbb rétegét az alkotmány képezi; annak elfogadásához, módosításához és eltörléséhez több szavazat szükséges, mint az egyszerú törvények esetében. Formai szempontból a szlovák jogforrási hierarchia nem tesz különbséget az alkotmány és az alkotmánytörvények között. ${ }^{8}$ Az alkotmánytörvények tehát e szempontból kétségkívül ugyanolyan jogerővel bírnak, mint az alkotmány, és kizárólag az alkotmánytörvények képesek azt közvetlenül módosítani, illetve kiegészíteni. ${ }^{9}$

A fentiek alapján tehát megállapítható, hogy Szlovákiában a különleges jogrendre vonatkozó szabályok kizárólag alkotmányos szinten kerültek rögzítésre. A szlovák jogrendben

4 Svák-Cibul'ka-Klíma, 2013, 97. o.

$5 \mathrm{Az}$ alkotmány a különleges jogrend szabályozási követelményeire vonatkozóan mindössze két felhatalmazó rendelkezést tartalmaz. Az 51. cikk (2) bekezdése értelmében „háború, hadiállapot, rendkívüli állapot vagy veszélyhelyzet esetén az alapvető jogok és szabadságok korlátozásának feltételeit és mértékét, valamint a kötelességek mértékét alkotmánytörvény állapítja meg”. A 102. cikk (3) bekezdése pedig kimondja, hogy „a hadüzenetre, hadiállapotra, rendkívüli állapotra, veszélyhelyzetre, valamint a háború, hadiállapot és rendkívüli állapot idején a közhatalom gyakorlására vonatkozó részletszabályokat alkotmányos törvény állapítja meg”.

6 Giba et al., 2019, 76. o.

7 Alkotmány 84. cikk (4) bekezdés.

8 I. ÚS 39/93 sz. határozat.

9 Giba et al., 2019, 75. o. 
azonban megjelennek egyéb, hagyományos értelemben különleges jogrendi esetkörnek nem minősülő esetek is, amelyek viszont törvényi szinten szabályozottak. ${ }^{10}$

Az állam biztonságáról szóló alkotmánytörvénynek megfelelően a különleges jogrend nevesített esetkörei a következők: háború (vojna), hadiállapot (vojnovýstav), rendkívüli állapot (výnimočný stav), veszélyhelyzet (núdzovýstav). ${ }^{11}$

Egyes szlovák szakirodalmi meghatározások alapján a háború olyan állami intézkedések összessége, amelyek révén a szükséges mértékben az állami és önkormányzati szervek, a gazdasági egységek és a társadalmi szervezetek tevékenysége az egész államban irányítható és korlátozható. ${ }^{12} \mathrm{~A}$ háború - mint különleges jogrendi esetkör - kapcsán az Állambiztonsági alk.tv. rögzíti, hogy annak kinyilvánítása a köztársasági elnök hatáskörébe tartozik, aki arról a Szlovák Köztársaság Nemzeti Tanácsa (a továbbiakban: parlament) határozata alapján dönt. A kinyilvánítás feltételeként a szlovák szabályozás két konkrét esetet jelöl meg: ha a Szlovák Köztársaságot idegen hatalom támadja meg hadüzenet kinyilvánításával, vagy ha az idegen hatalom hadüzenet kinyilvánítása nélkül sértette meg annak biztonságát, valamint ha a Szlovák Köztársaság nemzetközi szerződéses kapcsolataiból eredő kötelezettségeket teljesítve kerül háborús konfliktusba másokkal. ${ }^{13} \mathrm{~A}$ jogszabály a háború kapcsán úgy rendelkezik, hogy azt csak és kizárólag az ország teljes területére vonatkozóan lehet kinyilvánítani. Az Állambiztonsági alk.tv. meghatározza a háború időtartamát is: a háború a kinyilvánítás napjától a béke megkötésének napjáig tartó időszak. ${ }^{14} \mathrm{E}$ különleges jogrendi esetkör fennállása esetén a szükséges mértékben és a szükséges időtartamra a Szlovák Köztársaság teljes területén vagy annak egy részén az alapjogok és szabadságok korlátozás alá eshetnek, az események menetétôl függően kötelezettségek szabhatók. A bevezethető kötelezettségek és a korlátozások maximális mértéke taxatív módon felsorolásra kerültek a jogszabályban.

Szlovákiában a hadiállapot kinyilvánítására a köztársasági elnök jogosult, aki a kormány javaslatára cselekedhet. A háborúhoz hasonlóan a hadiállapot kinyilvánításához is teljesülniük kell bizonyos feltételeknek. Az Állambiztonsági alk.tv.-ben ilyen feltételként jelenik meg a hadüzenettel kapcsolatos közvetlen veszély fennállása, illetve ha az országot hadüzenet nélkül idegen hatalom közvetlen támadása fenyegeti. ${ }^{15} \mathrm{~A}$ hadiállapot kinyilvánítá-

10 A különleges jogrendet érintő szlovák szabályozásban szembetűnő érdekességként jelenik meg, hogy az alkotmányos szintủ szabályozás esetében a jogalkotó a stav (állapot) megnevezést alkalmazza, míg a törvényi szintủ szabályozás a különleges jogrendi esetköröknek nem minősülő esetekre a situácia (helyzet) megnevezést használja, ezzel is elősegítve az esetek minősítését követő helyes jogalkalmazást.

11 Bár a núdzový stav kifejezés magyarra fordítva szükségállapotot jelent, de tartalmát tekintve inkább a magyar veszélyhelyzethez áll közelebb, ezért is találkozunk a magyar nyelvú szakirodalmakban a veszélyhelyzet megnevezéssel. Lásd például: Németh, 2016. E kategória a továbbiakban veszélyhelyzet elnevezéssel kerül rögzítésre.

12 Šimák, 2005, 37. o.

13 Állambiztonsági alk.tv. 2. cikk (1) bekezdés.

14 Állambiztonsági alk.tv. 2. cikk (5) bekezdés.

15 Állambiztonsági alk.tv. 3. cikk (1) bekezdés. 
sának tekintetében a köztársasági elnöknek mérlegelési jogköre van, hiszen a kormány javaslatát bármikor jogában áll elutasítani.

A hadiállapot hatálya az egész ország területére kiterjed. ${ }^{16} \mathrm{E}$ különleges jogrendi esetkör kapcsán az Állambiztonsági alk.tv. arról is rendelkezik, hogy szükséges mértékben és a szükséges időtartamra az alapjogok és szabadságok korlátozás alá eshetnek, valamint a Szlovák Köztársaság teljes területén vagy annak egy részén, az események menetétól függően kötelezettségek szabhatók. ${ }^{17} \mathrm{~A}$ bevezethető kötelezettségeket és a korlátozások maximális mértékét taxatív módon az alkotmánytörvény sorolja fel.

Rendkívüli állapotot a köztársasági elnök a kormány javaslata alapján hirdethet ki, de kizárólag abban az esetben, ha terrortámadás vagy utcai zavargások közvetlen veszélye áll fenn, illetve ha ezek az események már bekövetkeztek. Az „utcai zavargások” a jogszabályban megfogalmazottak alapján egy olyan kiterjedt magatartás, amely a közhatalmi szervekkel szemben alkalmazott erőszakos cselekményekkel, üzletek és raktárak kifosztásával vagy egyéb, tulajdonra irányuló erőszakos cselekménnyel vagy más, tömeges erőszakos jogellenes cselekmény elkövetésével párosul, amely súlyosan fenyegeti a közbiztonságot, és amennyiben a rend helyreállítása a hatóságok fellépése révén, illetve más jogi eszközök alkalmazásával hatástalannak bizonyul. ${ }^{18} \mathrm{~A}$ hadiállapothoz hasonlóan a köztársasági elnök a rendkívüli állapot kihirdetésének tekintetében is mérlegelési jogkörrel rendelkezik, hiszen jogosult a kormány javaslatának elvetésére is.

A háborútól és a hadiállapottól eltérően, a rendkívüli állapot esetében a területi hatály tekintetében eltérés figyelhetô meg. Míg az előző kettő különleges jogrendi esetkört az ország egész területére kell elrendelni, addig a rendkívüli állapot esetében területi szempontból a kihirdetés hatálya kizárólag az érintett területre korlátozódik. E különleges jogrendi esetkör időtartama legfeljebb 60 nap lehet. Abban az esetben, amennyiben olyan új körülmények merülnek fel, amelyek közvetlenül kapcsolódnak a rendkívüli állapot kihirdetésének kiváltó okaihoz, a rendkívüli állapot további 30 nappal meghosszabbítható. A kihirdetés és a meghosszabbítás során is érvényesülniük kell a szükségesség és arányosság kritériumainak. ${ }^{19}$

A különleges jogrendi esetkörök negyedik kategóriájaként az Állambiztonsági alk.tv. a veszélyhelyzetet jelöli meg, amelynek kihirdetésére a kormány jogosult. A fentiekben már elemzett három különleges jogrendi esetkörrel ellentétben ebben az esetben nem szükséges a köztársasági elnök vagy a parlament utólagos jóváhagyása. A veszélyhelyzet akkor rendelhetô el, ha emberi életet és egészséget veszélyeztetô esemény következik be - vagy annak a közvetlen veszélye áll fenn -, okozati összefüggésben járványok bekövetkeztével, a természeti vagy más jelentős épített környezeti érték, ingatlan vagyon sérelmével összefüggésben, amelyet természeti szerencsétlenség, katasztrófa, ipari, szállítási vagy egyéb múködési 
baleset idéz elö. ${ }^{20} \mathrm{~A}$ veszélyhelyzet kihirdetésének területi hatálya megegyezik a rendkívüli állapotnál bemutatott területi hatállyal: a veszélyhelyzet kihirdetésének területi hatálya is csak az érintett területre korlátozódik. E különleges jogrendi esetkört a szükséges mértékben és a szükséges időtartamra, de legfeljebb 90 napra lehet kihirdetni.

A rendkívüli állapotot és a veszélyhelyzetet megvizsgálva láthatjuk, hogy a legalapvetőbb különbség a helyzet jellegére vonatkozik, amelyre az adott alkotmányos rezsim reagál - rendkívüli állapot esetén a veszélyt az emberek vagy embercsoportok védett érdekekkel szembeni támadásai jelentik, míg a veszélyhelyzet során az alkotmányos rezsim egy vis maior jellegú veszélyre vagy egy olyan veszélyre reagál, amelyet nem valamely személy vagy személycsoport szándékos jogellenes magatartása okoz. A veszélyhelyzet tehát inkább egy objektív jellegủ biztonsági helyzet veszélyére reagál. A másik jelentős különbség abban áll, hogy míg a rendkívüli állapotot a köztársasági elnök a kormány javaslata alapján hirdetheti ki, veszélyhelyzet esetében a kormány egymaga dönthet, természetesen a fent említett feltételek teljesülése mellett. ${ }^{21} \mathrm{~A}$ rendkívüli állapot és a veszélyhelyzet esetében közös pontként jelenik meg, hogy kihirdetésük jogszerúségéről, illetve az ezzel összefüggő döntések jogszerűségéről az alkotmány értelmében az alkotmánybíróság hivatott dönteni. ${ }^{22}$

A négy különleges jogrendi esetkör vizsgálata után megállapítható, hogy az állam külső szuverenitásának védelmére alapvetôen a háború és hadiállapot esetköreit, ${ }^{23}$ míg az állampolgárok és az állam belső biztonságának védelmére a rendkívüli állapot és a veszélyhelyzet esetköreit rendeli alkalmazni.

Ezen a ponton szükségesnek tartjuk megjegyezni, hogy a szlovák szabályozásban a koronavírus-járvány okozta helyzetre reagálva várhatóan 2020 decemberében az Állambiztonsági alk.tv. módosítására kerül sor, ami jelentős változásokat hoz a különleges jogrendi esetkörök tekintetében. Jelen fejezetben a kézirat lezártáig hatályos szabályozást mutatjuk be.

\subsection{Az alkotmányos szervek bemutatása és a különleges jogrendi tényállásokra vonatkozó közös szabályok}

Ahogy azt már fentebb említettük, az Állambiztonsági alk.tv. részletesen szabályozza az egyes alkotmányos szervek múködésének sajátos rendjét. Ilyen alkotmányos szervnek tekinthető a kormány, a minisztériumok és a központi szervek, a járási hivatalok, az önkormányzatok, valamint a megyei önkormányzatok. Kulcsfontosságú szervként jelenik meg e tekintetben továbbá a Szlovák Köztársaság Parlamenti Tanácsa (a továbbiakban: Parlamenti Tanács) és a Szlovák Köztársaság Biztonsági Tanácsa (a továbbiakban: Biztonsági Tanács) is, amelyek múködését az alábbiakban mutatjuk be röviden.

20 Állambiztonsági alk.tv. 5. cikk (1) bekezdés.

21 Škrobák, 2020.

22 Kelemen, 2020, 219. o. Lásd még: alkotmány 129. cikk (6) bekezdés.

23 Burdová, 2011, 57. 0. 
A szóban forgó jogszabály alapján kerül létrehozásra a Parlamenti Tanács (Parlamentná rada Slovenskej republiky), amely háború, hadiállapot és rendkívüli állapot idején a parlament feladatait hivatott ellátni. Az ellátott feladatok körében azonban meghatározott kivételek is találhatók. ${ }^{24}$ Egy nagyon speciális és kivételes szervról van szó, amely az előbbiekben felsorolt különleges jogrendi esetkörök életbelépése esetén a parlament alkotmányos hatáskörét gyakorolja abban az esetben, ha a parlament tevékenysége valamilyen okból akadályoztatva van. ${ }^{25}$

Szintén az Állambiztonsági alk.tv. alapján jön létre a Biztonsági Tanács (Bezpečnostná rada Slovenskej republiky), amelynek eltérő feladatai vannak különleges jogrend idején és békeidőben. ${ }^{26}$ Háború, hadiállapot és rendkívüli állapot idején a kormány akadályoztatása esetén a Biztonsági Tanács látja el annak feladatait. Az ellátott feladatok körében azonban meghatározott kivételek is találhatók: ilyen például a kormány programjának kialakítása és végrehajtása, a bizalmi szavazás iránti kérelem, valamint a közkegyelem gyakorlása. A Biztonsági Tanács békeidejû́ múködésérôl szóló törvény ${ }^{27}$ részletesen meghatározza a Biztonsági Tanács feladatait, amelyek elsősorban a következôk: a szlovák biztonsági rendszer kialakítása, a nemzetközi biztonsági kötelezettségek teljesítése, valamint a biztonsági helyzet kiértékelésével kapcsolatos javaslatok előkészítése. A Biztonsági Tanács kapcsán kiemelendő, hogy a jogszabály annak struktúráját is meghatározza. Eszerint a Biztonsági Tanács alegységei a kerületi biztonsági tanácsok és a járási biztonsági tanácsok.

Az Állambiztonsági alk.tv. közös rendelkezései szerint a hadüzenetről és a béke megkötéséről, a hadiállapot, a rendkívüli állapot és a veszélyhelyzet kihirdetéséról és megszüntetéséről, valamint az alapvető jogok és szabadságok korlátozásáról és a kötelezettségek kiszabásáról, továbbá a Parlamenti Tanács, a Biztonsági Tanács, a kerületi biztonsági tanácsok és a járási biztonsági tanácsok állásfoglalásáról szóló határozatok haladéktalanul közzétételre kerülnek a szlovák nyomtatott sajtóban, a rádióban és a televízió közvetítésében, illetve kihirdetésre kerülnek a Szlovák Köztársaság Törvénytárában. ${ }^{28}$

Az alkotmánytörvény rendezi a háború, hadiállapot vagy rendkívüli állapot fennállása idején az esedékes választások kérdéskörét, az állammal szembeni kártalanítási jogosultság esetköreit, a különleges jogrendi időszakban a törvényes határidők számításának és az elévülésnek a kérdéseit, továbbá rendelkezik a folyamatban lévő bírósági, közigazgatási és végrehajtási eljárási kérdésekről is. ${ }^{29}$

24 A kivételek taxatív felsorolása kapcsán lásd: Állambiztonsági alk.tv. 7. cikk (2) bekezdés.

25 Giba et al., 2019, 74. o.

26 A Biztonsági Tanács békeidőben a kormány tanácsadó testületeként vesz részt a Szlovák Köztársaság biztonsági rendszerének kialakításában és múködtetésében, teljesíti a nemzetközi biztonsági kötelezettségeket, felméri a belföldi és a külföldi biztonsági helyzetét; előkészíti a kormány számára a Szlovák Köztársaság biztonságának fenntartására, a válsághelyzetek megelőzésére irányuló intézkedésekre, valamint a válsághelyzet megoldására irányuló javaslatokat.

27 Zákon č. 110/2004 Z. z., o fungovaní Bezpečnostnej rady Slovenskej republiky v čase mieru (a továbbiakban: Biztonsági Tanács tv.).

28 Zbierka Zákonov Slovenskej republiky (a Szlovák Köztársaság hivatalos lapja).

29 Állambiztonsági alk.tv. 11. cikk. 


\subsection{A válsághelyzet és a rendkívüli helyzet mint a különleges jogrendnek nem minősülő rendkívüli felhatalmazás esetkörei}

A klasszikus értelemben vett különleges jogrendi tényállások mellett a szlovák jogi szabályozásban megjelenik két további esetkör is, amelyek nem tartoznak a különleges jogrendi esetkörök közé. Ezek a válsághelyzet (krízová situácia) és a rendkívüli helyzet (mimoriadna situácia). A rendkívüli helyzet azonban nem összekeverendő a különleges jogrendi esetkörnek minősülő rendkívüli állapottal.

A válsághelyzet fogalmának tisztázása tekintetében a háború és hadiállapoton kívüli válsághelyzetek kezeléséről szóló törvény ${ }^{30}$ tekinthető irányadónak. A jogszabályban foglaltak alapján válsághelyzet alatt olyan állapotot értünk, amelynek során az állam biztonsága sérül vagy veszélybe kerül, és az arra felhatalmazott alkotmányos szervek meghatározott feltételek beállta esetén kihirdetik a rendkívüli állapot, a veszélyhelyzet vagy a rendkívüli helyzet esetkörök egyikét. ${ }^{31} \mathrm{~A}$ szóban forgó törvényben a válságkezelés igazgatási szervei is rögzítésre kerültek, amelyek a következők: a kormány, a Biztonsági Tanács, a minisztériumok és a központi szervek, a Szlovák Nemzeti Bank, a kerületi biztonsági tanács, a körzeti hivatal, a járási biztonsági tanács és az önkormányzatok. Amint ebből a felsorolásból is kitúnik, a válságkezelő szervek és az általunk fent rögzített alkotmányos szervek között enyhe átfedés figyelhető meg. Megjegyzendő továbbá, hogy e törvény alapján a kormány a válsághelyzetek kezelése céljából felállíthatja a Központi Válságstábot (Ústredný krízový štáb) is, amelynek elnöke a belügyminiszter. A Központi Válságstáb múködésével kapcsolatos részletszabályokat a testület alapszabálya tartalmazza, amelyet a kormány hagy jóvá. ${ }^{32}$

A lakosság polgári védelméról szóló törvény ${ }^{33}$ a rendkívüli helyzetet egy olyan veszélyeztetési időszakként vagy egy rendkívüli eseményt követő időszak eredményeként határozza meg, amely negatív hatással van az életre, az egészségre vagy a vagyonra..$^{34} \mathrm{~A}$ jogszabály a rendkívüli helyzetek fajtáit is meghatározza. Ilyen rendkívüli helyzetnek minősülnek az elemi csapások, a balesetek, a különféle katasztrófák, a közegészségügyi veszélyhelyzetek és a terrorista támadások. Rendkívüli helyzet során olyan intézkedések bevezetésére kerülhet sor, amelyek az élet, az egészség vagy a vagyon megmentésére, a fenyegetés kockázatainak csökkentésére vagy egyéb olyan tevékenységre irányulnak, amelyek a rendkívüli esemény terjedésének és következményeinek megakadályozását eredményezik. ${ }^{35}$

30 Zákon č. 387/2002 Z. z., o riadení štátu v krízových situáciách mimo času vojny a vojnového stavu (a továbbiakban: Válsághelyzet tv.).

31 Válsághelyzet tv. 2. \$a) pont.

32 A Központi Válságstáb alapszabálya a Szlovák Köztársaság Kormányhivatalának oldaláról szlovák nyelven tölthető le: https://tinyurl.com/vdee4xc (Letöltve: 2020. december 15.).

33 Zákon č. 42/1994 Z. z., o civilnej ochrane obyvatel'stva (a továbbiakban: Polgári védelmi tv.).

34 Polgári védelmi tv. 3. \$ (1) bekezdés.

35 Polgári védelmi tv. 3 . $\$(1)$ bekezdés. 
A Polgári védelmi tv. célja a rendkívüli események bekövetkezte kapcsán a polgárok életének, egészségének és vagyonának védelme a rendkívüli események következményeivel szemben, továbbá az állami szervek múködési rendjének, valamint a természetes és jogi személyek feladatainak és kötelezettségeinek meghatározása. ${ }^{36} \mathrm{~A}$ polgári védelmi feladatok ellátása terén a törvény szerint a kormánynak vannak kiemelt feladatai, míg a belügyminiszter előkészítő, koordinációs, végrehajtási és ellenőrzési feladatokkal van megbízva. A fentebb felsorolt polgári védelmi szereplők feladatainak meghatározása kapcsán a törvény rendelkezik az érintettek jogairól, a károsultak segélyezéséről és kártalanításáról, a védelmi épületek kijelöléséről, valamint részletesen meghatározza az egyes kötelezettségek megszegése esetén kiszabható közigazgatási jogi szankciók körét.

\subsection{A különleges jogrendre való felkészülést segitő békeidejü szabályok, valamint a válságkezelésre vonatkozó szabályok}

Míg a különleges jogrendi esetkörökre vonatkozó szabályok a szlovák szabályozásban kizárólag alkotmányos szinten jelennek meg, addig a különleges jogrendet megelőző, illetve az arra való felkészülést szolgáló békeidejú szabályok törvényi szinten kerültek rögzítésre.

A téma kapcsán kiemelt jelentőséggel bír a már fentebb említett Válsághelyzeti tv., a Polgári védelmi tv., valamint a Biztonsági Tanács tv. Tekintettel jelen munka terjedelmi korlátaira, és mivel az előző fejezetben már részben szóltunk az első két törvényről, e ponton nem kerül sor azok részletes ismertetésére, azonban az alábbiakban röviden szólunk a Biztonsági Tanács békeidejü múködésérôl szóló törvényi szabályozásról.

A szóban forgó törvény részletesen meghatározza a Biztonsági Tanács üléseinek rendjét, tisztségviselőinek (elnökének és alelnökének) jogállását és feladatait, a Biztonsági Tanács egyes szakbizottságait, feladatköreit és múködését. A különleges jogrendre történő felkészülés kapcsán egyrészről a Biztonsági Tanácsnak mint békeidejü tanácsadó szervnek vannak kiemelkedő feladatai, másrészről pedig minden állami és önkormányzati szerv egy általános felhatalmazással van kötelezve a különleges jogrendi esetekre való felkészülésre. ${ }^{37}$

A Biztonsági Tanács tv. részletesen meghatározza a Biztonsági Tanács feladatait a szlovák biztonsági rendszer kialakításával, a nemzetközi biztonsági kötelezettségek teljesítésével, a biztonsági helyzet kiértékelésével, valamint a javaslatok előkészítésével kapcsolatban. A Biztonsági Tanács békeidőben a kormány tanácsadó testületeként vesz részt a Szlovák Köztársaság biztonsági rendszerének kialakításában és múködtetésében, teljesíti a nemzetközi biztonsági kötelezettségeket, felméri az állam belföldi és külföldi biztonsági helyzetét. Ezenfelül előkészíti a kormány számára a Szlovák Köztársaság biztonságának fenntartására, a válsághelyzetek megelőzésére irányuló intézkedésekre, valamint a válság-

36 Píry, 2020.

37 Állambiztonsági alk.tv. 6. cikk (3) bekezdés. 
helyzet megoldására irányuló javaslatokat. ${ }^{38} \mathrm{~A}$ Biztonsági Tanács elnöke a miniszterelnök, alelnöke a Biztonsági Tanács által felhatalmazott miniszterelnök-helyettes; további tagjai a védelemért felelős és a belügyekért felelős miniszter, a pénzügyminiszter és a külügyminiszter. A Biztonsági Tanács további tagjait a miniszterelnök javaslatára 48 órán belül a köztársasági elnök nevezi ki és menti fel. ${ }^{39}$

A Biztonsági Tanács az egyes szakterületek tekintetében önálló bizottságokban múködik:

— Külügyi Bizottság;

- Védelmiterv-bizottság;

- Polgárivédelmiterv-bizottság;

- Hírszerzési Bizottság;

- Energiabiztonsági Bizottság;

- Kiberbiztonsági Bizottság.

A Biztonsági Tanács bizottságainak tagjai kapcsán megfigyelhető, hogy az egyes szakterületek tekintetében a tagság a teljes központi közigazgatást lefedi - így például a Külügyi Bizottság tagjai a Külügyminisztérium, a Védelmi Minisztérium, a Belügyminisztérium, a Gazdasági Minisztérium, a Pénzügyminisztérium, a Közlekedési és Építésügyi Minisztérium, a Szlovák Köztársaság Kormányhivatala, a Szlovák Köztársaság Állami Tartalékalapja, a Nemzetbiztonsági Hivatal, a Köztársasági Elnök Hivatala, a Hírszerzési Szolgálat, valamint a Szlovák Nemzeti Bank képviselői. Az egyes szerveknek számtalan koordinációs és végrehajtási feladata van a különleges jogrendi helyzetekre való felkészülésben.

\section{Az alapjogok korlátozására vonatkozó szabályok különleges jogrend idején}

Az alapvetô emberi jogokkal és szabadságokkal kapcsolatos általános rendelkezéseket az alkotmány ${ }^{40}$ deklarálja. Bár az alkotmány garanciákat fogalmaz meg az alapjogok tekintetében, azonban azok különleges jogrend esetén történő korlátozhatóságának kérdését nem rendezi.

Az alkotmányban általános garanciaként jelenik meg az egyén szabadsága, az egyén egyenlősége méltóságában és jogaiban, továbbá az alkotmány deklarálja, hogy az alapvető jogok és szabadságok megvonhatatlanok, elidegeníthetetlenek, elévülhetetlenek és meg-

38 Állambiztonsági alk.tv. 8. cikk (2) bekezdés.

39 Állambiztonsági alk.tv. 8. cikk (4) bekezdés.

40 Alkotmány II. fejezet (Alapvetőjogokés szabadságjogok) 12. cikk. 
szüntethetetlenek, ${ }^{41}$ az alkotmány továbbá garantálja az alapvető jogok és szabadságjogok egyetemlegességét.

A szlovák alkotmány csupán két felhatalmazó rendelkezést tartalmaz a különleges jogrendre vonatkozó részletszabályok megalkotására vonatkozóan. A felhatalmazás alanya tekintetében az alkotmány azonban nem közöl további információkat. ${ }^{42} \mathrm{~A}$ különleges jogrendi esetkörök tekintetében az alkotmányban meghatározott felhatalmazás alapján az Állambiztonsági alk.tv. taxatíve felsorolja a különleges jogrendi esetek kapcsán az alapjogok korlátozásának megengedett szintjét és a korlátozható alapjogok és kötelezettségek körét. A jogszabály struktúráját követve, a bevezető rendelkezések után minden egyes különleges jogrendi esetkörnél taxatíve meghatározásra kerülnek az egyes korlátozható alapjogok és kötelezettségek.

A négy különleges jogrendi esetkör kapcsán megállapítható, hogy míg háború és hadiállapot esetén az alapvető jogok és szabadságok gyakorlásának korlátozása és a kötelezettségek teljesítésének követelményei csak a szükséges mértékben és a szükséges időre határozhatók meg, amelyeket az ország egészén vagy egyes területein zajló eseményektől függően szükséges meghatározni, addig a rendkívüli állapot és a veszélyhelyzet esetén a szabályozás a fenyegetés súlyától függően teszi lehetővé az alapjog-korlátozást. Tekintettel jelen munka terjedelmi korlátaira, valamint arra, hogy Szlovákia modern kori története során kizárólag veszélyhelyzet kihirdetésére került sor, e ponton eltekintenénk az összes, különleges jogrendi esetkör ideje alatt korlátozható alapjogok részletes ismertetésétól, csupán a veszélyhelyzet kihirdetése kapcsán rögzítenénk az egyes korlátozható alapjogokat.

Veszélyhelyzet idején az állam a szükségesség és arányosság elveinek teljesülése mellett korlátozhat bizonyos alapvető emberi jogokat, azonban azok korlátozása kizárólag az alkotmánnyal összhangban lehetséges. ${ }^{43} \mathrm{Az}$ alapjogok különleges jogrend idején - jelen esetben veszélyhelyzet idején - való korlátozhatóságáról, annak feltételeiről és terjedelméről, illetve az ezzel járó állampolgári kötelezettségekről az Állambiztonsági alk.tv. rendelkezik. ${ }^{44} \mathrm{~A} \mathrm{jog-}$ szabályban ezek taxatív módon kerültek felsorolásra.

A veszélyhelyzet által érintett vagy a közvetlen fenyegetés alatt álló területre a korlátozó intézkedések számos fajtája rendelhető el, mint például: személyek evakuálása, kötelező munkavégzés elöírása, magánhelyiségek katonai célra történő felhasználása, a gépjármû́használat megtiltása, postai küldemények kézbesítésének korlátozása, a szabad mozgás korlátozása, valamint a gyülekezési jog, sztrájkjog és a véleménynyilvánítási jog korlátozása. ${ }^{45}$

Az alkotmánytörvény által megengedett alapjog-korlátozás lehetőségét a Covid-19 okozta járványhelyzet ideje alatt a szlovák kormány is kihasználta. ${ }^{46} \mathrm{Az}$ alapjog-korlátozás kapcsán

41 Alkotmány 12. cikk (1) bekezdés.

42 Kelemen, 2019, 29. o.

43 Alkotmány 13. cikk (2) bekezdés.

44 Alkotmány 51. cikk (2) bekezdés.

45 Lásd bővebben az Állambiztonsági alk.tv. 5. cikk (3) bekezdését.

$46 \mathrm{Az}$ aktuális alapjog-korlátozó intézkedések kapcsán lásd a kormány október 28-án kibocsátott, 693/2020. számú határozatát. 
azonban mindenképpen szükségesnek tartjuk néhány szóban megemlíteni a közegészség védelméről, támogatásáról és fejlesztéséről szóló törvényt is, ${ }^{47}$ amelynek értelmében a Szlovák Köztársaság Közegészségügyi Hivatala - mint a közegészségügy területén illetékes államigazgatási hatóság - saját hatáskörben jogosult bizonyos intézkedések bevezetésére. Erre a szlovák alkotmány ad felhatalmazást, hiszen annak szabályozásából kitûnik, hogy a kötelezettségek és a korlátozások bevezetésére törvény (jelen esetben a Közeü.tv.) alapján kerülhet sor. ${ }^{48}$

A Szlovák Köztársaság Közegészségügyi Hivatalának e hatáskörét azonban számos vita övezte. ${ }^{49}$ Tekintettel arra a példa nélküli helyzetre, amelybe az egész világ látszólag egyik napról a másikra került, az illetékes hatóságoknak e tekintetben nem volt kidolgozott eljárásrendje. Erre való reakcióként a szlovák parlament rövidített jogalkotási eljárás keretében a Közeü.tv. módosítását fogadta el, amelyet Zuzana Čaputová államfő haladéktalanul aláirt. A módosítás célja az volt, hogy orvosolják az ellentmondásokat a Szlovák Közegészségügyi Hivatal koronavírus-járványra reagáló óvintézkedéseivel összefüggésben. A törvény aláírásával párhuzamosan azonban a köztársasági elnök azt is bejelentette, hogy a törvény bizonyos rendelkezései kapcsán az alkotmánybírósághoz fordul, ugyanis véleménye szerint a törvény azon rendelkezései, amelyek kizárják az óvintézkedések által érintett személyek kártérítésre való jogosultságát, alkotmányellenesek. Az alkotmánybíróság Čaputová beadványát jóváhagyta, a vitatott jogszabályhelyek hatályát felfüggesztette, majd a beadvány szövegét elbírálásra teljes egészében továbbutalta..$^{50}$

\section{A különleges jogrend kihirdetésének gyakorlati esetei}

Az előző fejezetekben elemzett különleges jogrendi esetkörök közül Szlovákiában ez idáig nem került sor sem a háború, sem a hadiállapot, ${ }^{51}$ sem pedig a rendkívüli állapot kihirdetésére. A veszélyhelyzet kihirdetése kapcsán azonban találunk gyakorlati példákat, hiszen Szlovákia modern kori történelme során ez idáig háromszor ${ }^{52}$ került sor e különleges jog-

47 Zákon č. 355/2007 Z. z., o ochrane, podpore a rozvoji verejného zdravia a o zmene a doplnení niektorých zákonov (a továbbiakban: Közeü.tv.).

48 Közeü.tv. 48. \$ (4) bekezdés.

49 Ehhez kapcsolódóan lásd: Havelková, 2020, 15. 0.; Havelková, 2020; Dobrovičová, 2020.

$50 \mathrm{Az}$ alkotmánybíróság 51/2020. sz. sajtóközleménye. Elérhető: www.ustavnysud.sk/documents/10182/ 107844303/TS_51_2020/c96cbo26-932e-4f15-8043-391be7018367 (Letöltve: 2020. december 2.).

51 Az 1918-ban létrejött, majd 1993-ban Csehországra és Szlovákiára kettévált Csehszlovákia esetében egyetlen alkalommal, a második világháború során került sor formálisan a hadiállapot kihirdetésére. 1941-ben Edvard Beneš, az emigrációba vonult csehszlovák államelnök kijelentette, hogy Csehszlovákia hadban áll a náci Németországgal, valamint Magyarországgal, mivel e két ország megsértette a csehszlovák állam szuverenitását.

52 Szlovákia legelőször 2011-ben, a 421/2011. sz. kormányhatározattal hirdetett veszélyhelyzetet az egészségügyi ellátórendszer hiányossága miatt. A veszélyhelyzet kihirdetése elsősorban arra irányult, hogy biztosítsa a folyamatos egészségügyi ellátást az országban, és megtiltsa bizonyos munkavállalói körök számára a sztrájkjog gyakorlását. 
rendi esetkör kihirdetésére - ebből két alkalom a koronavírus-járványhoz, illetve a 2020-as évhez köthetô. ${ }^{53}$ Mivel Szlovákiában a SARS-CoV-2 vírus okozta világjárvány miatt kétszer (az első és a második hullám ideje alatt) került sor a veszélyhelyzet kihirdetésére, ezért szükségesnek látjuk annak időszakonként történő bemutatását.

$\mathrm{Az}$ új típusú koronavírus okozta járványhelyzet miatt ${ }^{54}$ 2020. március 16-i hatállyal a szlovák kormány veszélyhelyzet kihirdetése mellett döntött. ${ }^{55} \mathrm{~A}$ kihirdetett különleges jogrendi esetkör hatálya azonban csak az egészségügyi rendszerre terjedt ki. Ahogy az már az előző fejezetekben is rögzítésre került, az Állambiztonsági alk.tv. a kihirdetés lehetőségét egy olyan esemény bekövetkeztéhez kapcsolja, amely az emberi életet, egészséget vagy vagyont veszélyezteti, vagy annak közvetlen veszélye áll fenn. Az alkotmánytörvény értelmében ilyen eseménynek minősül különösen a pandémia (járványhelyzet), a természeti vagy épített környezeti érték, illetve ingatlan vagyon sérelmével összefüggő olyan események, amelyeket természeti szerencsétlenség, katasztrófa, ipari, szállítási vagy egyéb múkködési baleset idéz elö. ${ }^{56}$ A veszélyhelyzet fontos jellemzőjeként jelenik meg, hogy az alkotmánytörvény értelmében a veszélyhelyzet ideje alatt az alapvető jogok és szabadságok korlátozás alá eshetnek. Ezen általános meghatározást követően a törvényben taxatív módon felsorolásra kerülnek a korlátozható alapjogok és szabadságok. Az alkotmánytörvény tehát nem ex constitutione korlátozza az alapjogokat, hanem lényegében felhatalmazást ad az alapjogok alkotmánytörvény szerinti korlátozására. Ezenfelül mindenképpen szükséges rögzítenünk, hogy a veszélyhelyzet kihirdetéséről szóló határozat önmagában nem bír általános korlátozó hatással, nem jelenti az összes alapvetô jog és szabadság korlátozását. ${ }^{57} \mathrm{~A}$ szlovák kormány még a veszélyhelyzet elrendelése elôtt, március 12-én 6:00 órától az egész ország területére kiterjedô"58 rendkívüli helyzetet hirdetett ki. ${ }^{59}$ Ez utóbbi azonban - a veszélyhelyzettel ellentétben -, ahogy már említettük, nem minősül hagyományos értelemben vett különleges jogrendi esetkörnek.

Látható tehát, hogy a szlovák kormány a koronavírus-járványra reagálva első ízben az egész országra kiterjedő rendkívüli helyzetet vezetett be, majd pár nappal később döntött a különleges jogrend bevezetése mellett. A rendkívüli helyzet és a veszélyhelyzet kihirdetése formailag egyaránt kormányhatározattal (uznesenie vlády) történt. ${ }^{60}$

53 Ennek kapcsán lásd a Szlovák Köztársaság Egészségügyi Minisztériumának honlapját: www.health.gov.sk/ Clanok?vyhlasenie-nudzoveho-stavu-v-zdravotnickych-zariadeniach (Letöltve: 2020. december 14.).

54 Venice Commission, 2020, 39. pont.

55 114/2020. sz. kormányhatározat.

56 Állambiztonsági alk.tv. 5. \$(1) bekezdés.

57 Drgonec, 2012, 76. o.

58 A rendkívüli helyzet kihirdetésére a Polgári védelmi tv. értelmében a másodfokú közegészségügyi veszély fennállása miatt került sor. Szlovákiában a rendkívüli helyzet egy nappal az Egészségügyi Világszervezet főigazgatója által 2020. március 11-én kihirdetett Covid-19-világjárványt követően került kihirdetésre.

59 111/2020. sz. kormányhatározat. A kormány a Polgári védelmi tv. 8. \$-a alapján volt jogosult a rendkívüli helyzet elrendelésére.

60 Jančát-Kostolanská-Leichmann-Šlajs, 2020. 
Szlovákiában a koronavírus-járvány első hulláma idején ${ }^{61}$ a veszélyhelyzetet a lehetséges maximális időtartamra, azaz 90 napra hirdették ki.62 Bár a különleges jogrend június 13-án véget ért, ${ }^{63}$ és nem került sor annak meghosszabbítására sem, a rendkívüli helyzet szabályai március 12-tôl a kézirat lezártáig továbbra is hatályban maradtak az országban. A rendkívüli helyzet kihirdetésének maximális időkerete a Polgári védelmi tv.-ben nem került rögzítésre, ${ }^{64}$ és ez idáig a szlovák kormány sem kezdeményezte annak visszavonását.

A koronavírus-járvány második hullámának következtében a szlovák kormány szintén az első hullám ideje alatt kihirdetésre kerülő különleges jogrendi esetkör bevezetése mellett döntött. Erre október 1-tôl 45 napig tartó időtartammal került sor. ${ }^{65} \mathrm{~A}$ veszélyhelyzet ebben az esetben is a rendkívüli helyzet szabályaival párhuzamosan került bevezetésre. ${ }^{66}$ 2020 novemberében a koronavírus-járvány második hullámának felszálló ága volt megfigyelhetô, ezért a kormány november 11-én újabb 45 nappal kényszerült meghosszabbítani a veszélyhelyzetet.

A koronavírus-járvány következtében elrendelt veszélyhelyzetek kapcsán azonban kiemelendő, hogy míg a márciusi veszélyhelyzet kifejezetten az egészségügyet érintette, addig az októberi, illetve novemberi veszélyhelyzet esetén inkább egy általános veszélyhelyzetről beszélhetünk.

E fejezeten belül szükségesnek tartunk néhány szót szólni azokról a közjogi-politikai vitákról is, amelyek a veszélyhelyzet kihirdetésével összefüggésben keletkeztek. Jelen munkában konkrétan három esetet kívánunk részletesebben ismertetni.

2011-ben a szlovák kórházakban dolgozó orvosok több mint egyharmadának egyidejû felmondása megrengette a szlovák kormányt, ezért az a veszélyhelyzet elrendelése mellett döntött. A kormányhatározatban kihirdetett veszélyhelyzet arra irányult, hogy biztosítsa a folyamatos egészségügyi ellátást, és megtiltsa bizonyos munkavállalók sztrájkjogának ${ }^{67}$ gyakorlását. Az eset kapcsán több alkotmánybírósági határozat is született. ${ }^{68}$ Leszögezendő azonban, hogy nem a különleges jogrendi esetkör kihirdetésével kapcsolatban, hanem a kényszermunka tilalmával összefüggésben kerültek vizsgálat alá a konkrét ügyek, amelyek során a szlovák alkotmánybíróság nem állapított meg alkotmányellenességet. Veszélyhelyzet

61 A koronavírus-járvány kezelésére (az első hullám idején) elfogadott főbb intézkedéseket az Európai Parlament Kutatószolgálata (European Parliamentary Research Service) is összegyüjtötte. Elérhető: www.europarl. europa.eu/RegData/etudes/BRIE/2020/652002/EPRS_BRI(2020)652002_EN.pdf (Letöltve: 2020. december 14.).

62 Vö. az Állambiztonsági alk.tv. 5. \$ (2) bekezdésével.

63 366/2020. sz. kormányhatározat.

64 Ennek kapcsán lásd: Polgári védelmi tv. 3b. \$ (3) bekezdés.

65 A szlovák kormány döntése értelmében a 2020. szeptember 30-án kihirdetett különleges jogrend október 1-től lépett hatályba. Ebben az esetben a szlovák kormány nem élt az Állambiztonsági alk.tv. által biztosított 90 napos időtartammal, így csupán 45 napra rendelte azt el.

66 268/2020. sz. kormányhatározat.

67 Megemlítendő, hogy a jogalkotó kizárólag a rendkívüli állapot esetkörénél szabályozza, hogy az nem hirdethetô ki a sztrájkjog érvényesülésének a megakadályozására.

68 Ehhez kapcsolódóan lásd az alkotmánybíróság határozatait: IV. ÚS 84/2012, I. ÚS 85/2012, I. ÚS 21/2012. 
kihirdetésére ezután csak 2020 márciusában és októberében, a koronavírus-járvány világjárvánnyá válása kapcsán került sor.

2020 októberében Viera Kováčiková föügyészhelyettes egy indítványt nyújtott be a veszélyhelyzet kapcsán az alkotmánybírósághoz. Az előterjesztés a kormány által elfogadott határozat alkotmányosságával kapcsolatban született meg. Ezenfelül az ellenzéki képviselők egy csoportja is az alkotmánybírósághoz fordult a veszélyhelyzet kihirdetése kapcsán. Az alkotmánybíróság 10 napon belül, október 14-én döntött ${ }^{69}$ arról, hogy az október 1-jei hatállyal meghirdetett veszélyhelyzet összhangban van a szlovák alkotmánnyal, sőt, a veszélyhelyzet kihirdetése az alkotmány mellett az Állambiztonsági alk.tv.-t sem sérti. Az alkotmánybíróság úgy ítélte meg, hogy a veszélyhelyzet kihirdetése nem ütközik az alkotmányba, és az sem alkotmányellenes, hogy hatálya az egész ország területére vonatkozik. A fentieken kívül az alkotmánybíróság szerint a kormány a veszélyhelyzet kihirdetésének minden formális követelményét teljesítette. A Szlovák Köztársaság Hírügynökségének (TASR) tájékoztatása alapján Mária Kolíková igazságügyi miniszter a veszélyhelyzet meghosszabbításával összefüggésben támogatni fogja az Állambiztonsági alk.tv. esetleges módosítását annak érdekében, hogy a törvény összhangban legyen az aktuálisan kialakult helyzettel.70

Szintén 2020 októberében látott napvilágot az a hír is, amely alapján a Föügyészség szerint a Szlovák Közegészségügyi Hivatal törvényt sértett a koronavírus-járvány első hulláma idején kihirdetett veszélyhelyzet alatti óvintézkedések elrendelése tekintetében, ezért a Főügyészség ügyészi figyelmeztetést küldött a Közegészségügyi Hivatalnak. A törvénysértés elsősorban azzal függött össze, hogy a Közegészségügyi Hivatalnak a rendkívüli helyzet és a veszélyhelyzet kihirdetése után már nem volt megfelelő hatásköre az óvintézkedések elrendelésére, és az intézkedések jogi formája sem volt megfelelő. Az ügyészség azt javasolta a Közegészségügyi Hivatalnak, hogy késedelem nélkül hozza meg a szükséges intézkedéseket, hogy a jövőben elejét vegyék a hatályos jogszabályok megsértésének. A dokumentumból az is kiderül, hogy az ügyészség nem az intézkedéseket, hanem azok elfogadásának módját kifogásolta. ${ }^{71}$

\section{4. Összegzés}

Szlovákiában a különleges jogrendre vonatkozó szabályok kizárólag alkotmányos szinten, a Szlovák Köztársaság Alkotmányában, illetve az Állambiztonsági alk.tv.-ben szerepelnek. Míg az alkotmányban a különleges jogrendre vonatkozó általános szabályok ta-

69 Az alkotmánybíróság 47/2020. sz. sajtóközleménye.

70 A Szlovák Köztársaság Hírügynökségének sajtóhíre a következő linken érhetô el: www.tasr.sk/tasr-clanok/ TASR:20201110TBA03162 (Letöltve: 2020. november 10.).

71 A Szlovák Köztársaság Hírügynökségének sajtóhíre a következő linken érhető el: www.tasr.sk/tasr-clanok/ TASR:20201006TBB00246 (Letöltve: 2020. november 10.). 
lálhatók, addig az alkotmánytörvény az egyes különleges jogrendi esetkörökre vonatkozó részletszabályokat fogalmazza meg. A szlovák jogrendben továbbá megjelennek egyéb, hagyományos értelemben különleges jogrendi esetkörnek nem minősülő esetek is, amelyek törvényi szinten kerültek szabályozásra.

A szlovák szabályozás a különleges jogrendi esetkörök négy kategóriáját különbözteti meg: a háborút, a hadiállapotot, a rendkívüli állapotot és a veszélyhelyzetet. Ezenfelül azonban a klasszikus értelemben vett különleges jogrendi esetkörök mellett feltûnnek a rendkívüli helyzet és a válsághelyzet kategóriák is. Míg előbbit a Polgári védelmi tv. szabályozza, utóbbi a háború és hadiállapoton kívüli válsághelyzetek kezeléséről szóló törvényben került rögzítésre.

Háború kérdésében a köztársasági elnök a parlament határozata alapján hivatott dönteni. A hadiállapot és a rendkívüli állapot kihirdetése kapcsán szintén a köztársasági elnök kezében összpontosul a döntés joga, aki a kormány javaslatára mérlegelheti e különleges jogrendi esetkör kihirdetésének lehetőségét. Veszélyhelyzet esetén a kormány egymaga jogosult annak kihirdetésére. Amennyiben a háború, hadiállapot és rendkívüli állapot idején a parlament akadályoztatva van, az Állambiztonsági alk.tv. rendelkezik az úgynevezett Parlamenti Tanács létrehozásáról. A Parlamenti Tanács a parlament hatásköreit gyakorolja. Kivételt képeznek ezalól az Állambiztonsági alk.tv.-ben az alábbi, taxatíve felsorolt esetek. Ezek alapján a Parlamenti Tanács:

— nem határozhat az alkotmány, az egyes alkotmánytörvények, a választási törvény, a politikai pártokról szóló törvény és a népszavazásról szóló törvény módosításáról;

— nem jogosult nemzetközi szerződés kötelező hatályának elismerésére;

- nem indítványozhat népszavazást a köztársasági elnök felmentéséről, és nem határozhat népszavazás kiírásáról;

— nem kezdeményezhet vádemelést a köztársasági elnök ellen.

Szintén az Állambiztonsági alk.tv. alapján hozzák létre a Biztonsági Tanácsot, amely a kormány háború, hadiállapot és rendkívüli állapot idején való akadályoztatása esetén látja el annak legfőbb feladatait. A Biztonsági Tanács kapcsán kiemelendő, hogy annak eltérő feladatai vannak a különleges jogrend idején és békeidőben. Míg különleges jogrend idején az Állambiztonsági alk.tv. szabályozza a Biztonsági Tanács múködését, addig békeidőben a Biztonsági Tanács békeidejú múködéséről szóló törvény alapján szükséges eljárni.

Az alábbi táblázatban összefoglaltuk a szlovák különleges jogrendi szabályozással kapcsolatos legfontosabb tudnivalókat. 


\begin{tabular}{|c|c|c|c|c|}
\hline & Háború & Hadiállapot & $\begin{array}{l}\text { Rendkívüli } \\
\text { állapot }\end{array}$ & Veszélyhelyzet \\
\hline $\begin{array}{c}\text { Szabályozás } \\
\text { szintje }\end{array}$ & \multicolumn{4}{|c|}{ Alkotmányos (alkotmány és Állambiztonsági alk.tv.) } \\
\hline $\begin{array}{c}\text { Elrendelési } \\
\text { okok }\end{array}$ & $\begin{array}{l}\text { Idegen hatalom tá- } \\
\text { madása a hadüzenet } \\
\text { kinyilvánításával } \\
\text { vagy anélkül, } \\
\text { vagy } \\
\text { nemzetközi szerző- } \\
\text { désből eredő kötele- } \\
\text { zettségek teljesítése } \\
\text { során kerül az ország } \\
\text { háborús konflik- } \\
\text { tusba másokkal. }\end{array}$ & $\begin{array}{l}\text { Az országot a háború } \\
\text { közvetlen veszélye } \\
\text { fenyegeti, } \\
\text { vagy } \\
\text { az országot a háború } \\
\text { kinyilvánítása nélkül } \\
\text { idegen hatalom } \\
\text { közvetlen támadása } \\
\text { fenyegeti. }\end{array}$ & $\begin{array}{l}\text { Terrortámadás } \\
\text { vagy } \\
\text { utcai zavargások } \\
\text { vagy } \\
\text { a fentiek bekövet- } \\
\text { keztének köz- } \\
\text { vetlen veszélye áll } \\
\text { fenn. }\end{array}$ & $\begin{array}{l}\text { Az emberi életet } \\
\text { és egészséget } \\
\text { veszélyeztető } \\
\text { esemény } \\
\text { bekövetkezte } \\
\text { vagy } \\
\text { bekövetkez- } \\
\text { tének közvetlen } \\
\text { fenyegetése. }\end{array}$ \\
\hline Elrendelés & $\begin{array}{l}\text { A köztársasági elnök } \\
\text { a parlament hatá- } \\
\text { rozata alapján }\end{array}$ & $\begin{array}{l}\text { A köztársasági elnök } \\
\text { a kormány javaslatára }\end{array}$ & $\begin{array}{l}\text { A köztársasági } \\
\text { elnök a kormány } \\
\text { javaslatára }\end{array}$ & Kormány \\
\hline $\begin{array}{l}\text { Gyakorlati } \\
\text { esetek }\end{array}$ & \multicolumn{3}{|c|}{ Ez idáig egyszer sem került kihirdetésre. } & $\begin{array}{l}\text { Ezzel kapcso- } \\
\text { latban lásd A kü- } \\
\text { lönleges jogrend } \\
\text { kihirdetésének } \\
\text { gyakorlati esetei } \\
\text { címú részt. }\end{array}$ \\
\hline $\begin{array}{c}\text { Különleges } \\
\text { jogrendnek } \\
\text { nem } \\
\text { minősülő } \\
\text { esetek }\end{array}$ & \multicolumn{4}{|l|}{$\begin{array}{l}\text { Válsághelyzet } \\
\text { Rendkívüli helyzet }\end{array}$} \\
\hline
\end{tabular}

22. táblázat

A Szlovák Köztársaság különleges jogrendi szabályainak összegzése Forrás: a szerzők sajátösszeállítása

Az alapjogok korlátozása tekintetében megállapítható, hogy az alkotmány csupán bizonyos garanciákat fogalmaz meg az alapjogokkal kapcsolatban, azonban azok különleges 
jogrend idején történő korlátozhatóságát nem rendezi. A különleges jogrendre vonatkozóan az alkotmányban foglalt meghatározott felhatalmazás alapján az Állambiztonsági alk.tv. taxatíve felsorolja a különleges jogrendi esetkörök tekintetében az alapjogok korlátozásának megengedett szintjét és a korlátozható alapjogok és kötelezettségek körét.

A különleges jogrend gyakorlati esetei kapcsán rögzítendő, hogy a Szlovák Köztársaság modern kori történelme során kizárólag a veszélyhelyzet kihirdetésére került sor. E gyakorlati példák közül két alkalom a koronavírus-járványhoz, tehát a 2020-as évhez köthető. Amennyiben nem „csak” Szlovákia, hanem Csehszlovákia történelmét vizsgáljuk (tehát az 1918-1993 közötti időszakot), megfigyelhető, hogy ebben az időszakban egyetlen alkalommal, 1941-ben került sor a hadiállapot kihirdetésére.

Ami a magyar szabályozással való összehasonlítást illeti, megállapítható, hogy a különleges jogrendi esetkörök szabályozása mindkét országban alkotmányos szinten került rögzítésre. Különbség mutatkozik azonban az elrendelhető különleges jogrendi esetkörök számának tekintetében - ez Szlovákiában négy, míg Magyarországon hat kategóriát takar. Az Alaptörvény kilencedik módosítása értelmében azonban a különleges jogrendi esetkörök szúkítése és átfogó szabályozásának módosítása figyelhetô meg. Ez azt eredményezi, hogy a meglévő hat különleges jogrendi esetkör (rendkívüli állapot, szükségállapot, megelőző védelmi helyzet, terrorveszélyhelyzet, váratlan támadás, veszélyhelyzet) háromra csökken (hadiállapot, szükségállapot, veszélyhelyzet). Így a kilencedik módosítás révén létrejövő különleges jogrendi esetkörök több ponton is hasonlóságot mutatnak a jelenleg is hatályos szlovák különleges jogrendi szabályozással.

A szlovák szabályozás szerinti háború és hadiállapot kategóriái a magyar szabályozásban a kilencedik Alaptörvény-módosítás után összevontan hadiállapotként jelenik meg.

Az Alaptörvény-módosítás által bevezetett szükségállapottal nagymértékú hasonlóságot mutat a szlovák rendkívüli állapot. Míg a rendkívüli állapot Szlovákiában csak terrortámadás vagy utcai zavargások következtében vagy ezek bekövetkeztének közvetlen veszélye esetén hirdethető ki, addig a magyar szabályozásból ismert szükségállapot az alkotmányos rend megdöntésére, felforgatására vagy a hatalom kizárólagos megszerzésére irányuló cselekmény esetén, illetve az élet- és vagyonbiztonságot tömeges mértékben veszélyeztető jogellenes cselekmény esetén hirdethető ki. Mindkét esetkör tekintetében közös vonásként jelenik meg, hogy az elrendelésük oka mindig valamilyen más személyek által kiváltott jogellenes cselekményen alapszik.

A veszélyhelyzet mint különleges jogrendi esetkör a szlovák és a magyar szabályozásban egyaránt elrendelhető valamilyen életet és egészséget veszélyeztető esemény bekövetkezte vagy bekövetkeztének közvetlen fenyegetése miatt. A két esetkörben közös, hogy mindig valamilyen külső, előre nem látható esemény szolgáltat okot a különleges jogrendi esetkörök ezen típusának bevezetésére.

Szintén a két nemzeti szabályozás közös vonásaként jelenik meg, hogy a magyar Honvédelmi Tanácshoz hasonló, a rendkívüli állapotban az államfö, a parlament és a kormány 
szerepét is átvevő testületre találunk hasonló példát a szlovák jogi szabályozásban: Szlovákiában ilyen szerv a Parlamenti Tanács (a parlament akadályoztatása esetén) és a Biztonsági Tanács (a kormány akadályoztatása esetén). A kilencedik Alaptörvény-módosítás azonban a Honvédelmi Tanácsot megszünteti, feladatait a Kormány hatáskörébe utalja, ezzel is megerősítve a Kormány különleges jogrend idején betöltött szerepét.

Szintén közös vonásként jelenik meg, hogy a szlovák és a magyar szabályozás egyaránt alkotmányos szinten rendelkezik az alapjog-korlátozás legfontosabb szabályairól. A szlovák alkotmányhoz hasonlóan az Alaptörvényben is megtalálható az általános alapjog-korlátozási klauzula. Az alapjogok különleges jogrend esetén történő korlátozása tekintetében szintén hasonlóság mutatkozik, hiszen mindkét nemzeti szabályozásban megtalálható az alapjogok különleges jogrend esetén felmerülő korlátozhatósága. Különbséget láthatunk azonban az alapjog-korlátozás részletszabályai tekintetében - míg ezek Szlovákia esetében alkotmányos szinten, az Állambiztonsági alk.tv.-ben kerültek szabályozásra, addig Magyarországon e szabályozás tekintetében a törvényi szint az irányadó.

\section{Irodalomjegyzék}

BuRdová, L. (2011) 'Negatívní sociální jevy - možné zdroje ohrožení vnitřní bezpečnosti' in Suja, M. (szerk.) Zborník Metodológia a metodika analýzy zdrojov ohrozenia vnútornej bezpečnosti SR. 1. kiadás. Bratislava: Akadémia Policajného zboru v Bratislave

DoBRovičovÁ, G. (2020) Niekol'ko poznámok $k$ opatreniam Úradu verejného zdravotníctva Slovenskej republiky [Online]. Elérhető: https://comeniusblog.flaw.uniba.sk/2020/11/09/ niekolko-poznamok-k-opatreniam-uradu-verejneho-zdravotnictva-slovenskejrepubliky/ (Letöltve: 2020. december 13.)

DRGONEC, J. (2019) Ústava Slovenskej republiky. 2. kiadás. Bratislava: C. H. Beck

DRGONEC, J. (2012) 'Podmienky a právny účinok vyhlásenia núdzového stavu', Justičná revue, 64(1), 61-86. o.

FARKAS, Á., KelEMEN, R. (szerk.) (2020) Szkülla és Kharübdisz között-Tanulmányok a különleges jogrend elméleti és pragmatikus kérdéseiről, valamint nemzetközi megoldásairól. 1. kiadás. Budapest: Magyar Katonai Jogi és Hadijogi Társaság

GiBA, M. et al. (2019) Ústavné právo. 1. kiadás. Bratislava: Wolters Kluwer

Havelkové, M. (2020) 'Kompetencia nariad'ovat protipandemické opatrenia v čase trvania núdzového stavu a mimoriadnej situácie', COMENIUS časopis, 2020/2, 15-25. o.

Havelková, M. (2020) Metódy a formy činnosti verejnej správyv čase pandémie [Online]. Elérhetô: https://comeniusblog.flaw.uniba.sk/2020/04/25/metody-a-formy-cinnosti-verejnejspravy-v-case-pandemie-2-cast/ (Letöltve: 2020. december 1.)

JANČÁT, L., KostolansKÁ, E., LEICHMANN, J., ŠLAJS, J. (2020) 'Vyhlašování a soudní př̌eskum zvláštních stavů ve vybraných státech', Právní rozhledy, 27(13-14), 510-514. o. 
Kelemen, R. (2019) 'Az Alaptörvény szükségállapot-szabályozásának kritikai áttekintése az egyes európai uniós tagállamok alkotmányainak figyelembevételével - Különös tekintettel a visegrádi államok alkotmányaira' in Bartkó, R. (szerk.) A terrorizmus elleni küzdelem aktuális kérdései a XXI. században. 1. kiadás. Budapest: Gondolat Kiadó

MAJERČÁk, T. (2008) 'Ústavná koncepcia osobných práv a slobôd', Právny obzor, 91(1), 16-29. o. NÉMETH, L. (szerk.) (2016) Nemzetialkotmányokaz EU-ban. 1. kiadás. Budapest: Wolters Kluwer PíRY, M. (2020) Základné práva a povinnosti v čase pandémie, správne delikty a trestná činnost'. [Online]. Elérhető: www.epi.sk/odborny-clanok/zakladne-prava-a-povinnosti-v-casepandemie-spravne-delikty-a-trestna-cinnost.htm (Letöltve: 2020 . november 19.)

Svák, J., Cibul'Ka, L'., KlímA, K. (2013) Ústavné právo Slovenskej republiky (Všeobecná čast'). 4. kiadás. Žilina: Eurokódex a Paneurópska vysoká škola

ŠıмÁk, L. et al. (2005) Terminologický slovník krízového riadenia. 1. kiadás. Žilina: Fakulta špeciálneho inžinierstva Žilinskej Univerzity v Žiline

Šкroвák, J. (2020) Správne právo v časoch pandémie koronavírusu. Čast' prvá: Núdzový stav(?) [Online]. Elérhető: https://comeniusblog.flaw.uniba.sk/2020/03/15/spravne-pravo-vcasoch-pandemie-koronavirusu-cast-prva-nudzovy-stav/ (Letöltve: 2020. november 4.)

Venice Commission (2020) Interim Report on the Measures Taken in the EU Member States as a Result of the COVID-19 Crisis and Their Impact on Democracy, the Rule of Law and Fundamental Rights (Study No. 995/2020) [Online]. Elérhetô: www.venice.coe.int/webforms/ documents/?pdf=CDL-AD(2020)018-e (Letöltve: 2020 . december 15.) 